\author{
JOANNA DOMINIAK \\ Uniwersytet im. Adama Mickiewicza w Poznaniu, Polska • Adam Mickiewicz University \\ in Poznań, Poland
}

\title{
Poziom wykorzystania usług elektronicznych przez firmy i gospodarstwa domowe województwa wielkopolskiego
}

\author{
The Level of Use of e-services by Firms and Households in Wielkopolska
}

\begin{abstract}
Streszczenie: Postęp technologiczny, szczególnie w sektorze technologii informacyjno-telekomunikacyjnej (ITC), zapoczątkował wiele zmian $\mathrm{w}$ dotychczasowej organizacji działalności usługowej. Istotnym aspektem przemian organizacyjnych w sferze usług jest rozwój nowych form świadczenia i dystrybucji tradycyjnych usług, wykorzystujących techniki komputerowe i sieć internetową, czyli tzw. usług elektronicznych (e-usług). Rozwój tej formy świadczenia usług nastąpił niemal w każdej działalności usługowej, która nie wymaga bezpośredniego kontaktu usługodawcy i usługobiorcy, a szczególnie zauważalny jest w handlu (handel elektroniczny), administracji (elektroniczna administracja) czy edukacji (zdalna edukacja). Proces ten, uwarunkowany dostępnością sieci internetowej, został zapoczątkowany w Polsce w latach dziewięćdziesiątych. Początkowo dostęp sieci globalnej umożliwiał głównie komunikację między przedsiębiorstwami, które położone były w różnych miejscach świata. Dziś dostęp do internetu jest coraz bardziej powszechny i powoduje duże zmiany w funkcjonowaniu zarówno przedsiębiorstw, jak i gospodarstw domowych. Głównym celem artykułu jest analiza stopnia wykorzystania usług elektronicznych przez gospodarstwa domowe oraz przedsiębiorstwa na terenie województwa wielkopolskiego. Analiza ta została oparta na wynikach badań ankietowych przeprowadzonych na próbie przedsiębiorstw i gospodarstw domowych, które dotyczyły rodzajów usług elektronicznych, częstotliwości i motywów ich wykorzystania, a także barier ograniczających to korzystanie.
\end{abstract}

\begin{abstract}
Technological progress, especially in the information and communication technology sector (ITC) has initiated a series of changes in the existing organization of service activities. An important aspect of the organizational change in the services sector is the development of new forms of provision and distribution of traditional service with the use of computer technology and the Internet the so-called electronic services (e-services). The development of this form of service provision has occurred in almost every service activity that does not require direct contact between the provider and the recipient, and is particularly notable trade (e-commerce), public administration (e-government) and education (e-learning). This process, determined by access to the Intranet network, was launched in Poland in the 1990s Initially, access to the global network enabled communication mainly between firms located in different places of the world. Today, Internet access has become more widespread and causes significant changes in the operation of both firms and households. The main aim of this article is to analyze the scale of use of electronic services by households and businesses in the region of Wielkopolska. The analysis was based on the results of a survey conducted on a sample of businesses and households, which concerned the types of electronic services, the frequency and motives of their use, as well as barriers to such use.
\end{abstract}

Słowa kluczowe: elektroniczna administracja; gospodarstwa domowe; handel elektroniczny; przedsiębiorstwa; usługi elektroniczne; Wielkopolska

Keywords: businesses; e-commerce; e-government; e-services; households; Wielkopolska 
Otrzymano: 19 grudnia 2015

Received: 19 December 2015

Zaakceptowano: 21 lipca 2016

Accepted: 21 July 2016

\section{Sugerowana cytacja / Suggested citation:}

Dominiak, J. (2016). Poziom wykorzystania usług elektronicznych przez firmy i gospodarstwa domowe województwa wielkopolskiego. Prace Komisji Geografii Przemysłu Polskiego Towarzystwa Geograficznego, 30(4), $35-49$.

\section{WSTĘP}

Postęp technologiczny, szczególnie w sektorze technologii informacyjno-telekomunikacyjnej (ITC), zapoczątkował wiele zmian w dotychczasowej organizacji działalności usługowej. Istotnym aspektem przemian organizacyjnych w sferze usług jest rozwój nowych form świadczenia i dystrybucji tradycyjnych usług, wykorzystujących technikę komputerową i sieć internetową, czyli tzw. usług elektronicznych (e-usług). Rozwój tej formy świadczenia usług nastąpił niemal w każdej działalności usługowej, która nie wymaga bezpośredniego kontaktu usługodawcy i usługobiorcy, a szczególnie zauważalny jest w handlu (handel elektroniczny), administracji (elektroniczna administracja) czy edukacji (zdalna edukacja).

Proces ten, uwarunkowany dostępnością sieci internetowej, został zapoczątkowany w Polsce w latach dziewięćdziesiątych. Początkowo dostęp do globalnej sieci umożliwiał głównie komunikację między przedsiębiorstwami, które położone były w różnych miejscach świata. Dziś dostęp do internetu jest coraz powszechniejszy i powoduje istotne zmiany w funkcjonowaniu zarówno przedsiębiorstw, jak i gospodarstw domowych. Według Castellsa (2007: 86): „Nowe technologie informacyjne, zmieniające charakter procesów przetwarzania informacji, wpływają na wszystkie sfery działalności człowieka i umożliwiają ustanawianie nieograniczonych powiązań zarówno między różnymi sferami, jak i między elementami oraz podmiotami takich działalności. Wyłania się usieciowiona gospodarka głębokich współzależności, która w coraz większym stopniu potrafi wykorzystać swój postęp w sferze techniki, wiedzy i zarządzania".

Nowe działy produkcyjne i usługowe nowoczesnej gospodarki wykorzystują technologie informacyjno-komunikacyjne. Technologie ICT umożliwiają również produkcję nowych lub znacznie ulepszonych produktów w tradycyjnych branżach przemysłowych, a w odniesieniu do usług prowadzą do modyfikacji i usprawniania różnych ich typów, np.: edukacyjnych, finansowych, medycznych i administracyjnych.

Rozwój technik informacyjno-telekomunikacyjnych prowadzi także do zasadniczych zmian w życiu społeczeństw. Wraz z upowszechnieniem się ICT pojawiły się nowe możliwości zdobywania informacji, a także nauki, pracy, dokonywania zakupów czy spędzania czasu wolnego. Postęp w dziedzinie ICT sprzyja procesowi kształtowania się społeczeństwa informacyjnego (Dominiak, 2008).

Zastosowanie ICT w sferze usług doprowadziło do przemian właściwie w każdej ich dziedzinie. Duża część usług może być świadczona częściowo bądź całkowicie, opierając się jedynie na sieci teleinformatycznej. Upowszechnienie się internetu wywołało 
duże zmiany w świadczeniu usług handlowych. Powstały nowe ścieżki dystrybucji w postaci sieci internetowej, które sprzyjają zwiększaniu się rynków zbytu oraz umożliwiają znaczną obniżkę kosztów działalności gospodarczej. Internet odgrywa ważną rolę $\mathrm{w}$ bankowości, ubezpieczeniach, ale także w doradztwie, księgowości i innych usługach dla biznesu. Rozwój ICT spowodował też przemiany w sferze edukacji i administracji. Impulsem dla rozwoju zdalnego nauczania stały się interaktywne techniki dostępu do zasobów informacyjnych internetu i multimedia. Te same narzędzia i technologie umożliwiają automatyzację rutynowych czynności z zakresu administracji publicznej, bez konieczności osobistego kontaktu urzędnika i petenta (Werner, 2003). Coraz większe znaczenie internet ma również w medycynie, zapewniając zarówno dostęp do informacji, jak i zdalne diagnozowanie oraz konsultacje medyczne (Dominiak, 2008).

Rozwój ICT umożliwił najważniejszą innowację w zakresie form świadczenia usług - rozwój usług elektronicznych. Usługi elektroniczne (e-usługi) to rodzaj usług, które świadczone są za pomocą technologii informacyjno-telekomunikacyjnych, przy wykorzystaniu takich urządzeń, jak komputer czy telefon komórkowy, oraz przy użyciu sieci internet. Technika elektroniczna umożliwia realizację świadczenia usługi bez konieczności bezpośredniego kontaktu między usługodawcą a klientem, co prowadzi do znacznego ograniczenia roli odległości geograficznej w procesie świadczenia usług.

Efektem zastosowania technologii informatyczno-telekomunikacyjnych w sferze usług są korzyści zarówno dla firm, jak i dla odbiorców indywidualnych. Rozwój usług elektronicznych umożliwia rozszerzanie rynków zbytu, obniżenie kosztów działalności gospodarczej, co prowadzi z kolei do zwiększenia zysku. Korzyści dla odbiorców indywidualnych związane są ze zwiększeniem dostępności usług i produktów, większą możliwością wyboru produktów i usług, dostępem do informacji oraz oszczędnością czasu. Wiele z tych korzyści ma charakter jakościowy, np. poprawienie jakości obsługi, wygoda klientów, łatwość dostępu do informacji (Goliński, 2004).

Głównym celem artykułu jest analiza stopnia wykorzystania usług elektronicznych przez gospodarstwa domowe i przedsiębiorstwa na terenie województwa wielkopolskiego. Analiza ta została oparta na wynikach badań ankietowych przeprowadzonych na próbie przedsiębiorstw i gospodarstw domowych, które dotyczyły rodzajów wykorzystywanych usług elektronicznych, częstotliwości i motywów ich wykorzystania, a także barier ograniczających to korzystanie. Badanie zostało przeprowadzone w 2014 roku na próbie 508 przedsiębiorstw oraz 656 gospodarstw domowych.

\section{USTALENIA TERMINOLOGICZNE}

Najprościej usługi elektroniczne są definiowane w literaturze jako usługi dostarczane poprzez sieć (Rust, Kannan; 2003). Rust (2004) wskazuje, że współczesny rozwój technologiczny daje usługodawcom nowe narzędzia i możliwości w tym zakresie. W polskiej literaturze przedmiotu usługi elektroniczne najczęściej definiuje się jako nową formę świadczenia usług przy wykorzystaniu internetu, na indywidualne żądanie usługobiorcy, bez jednoczesnej obecności stron w tej samej lokalizacji (Dominiak, 2008; Dąbrowska, Janoś-Kresło, Wódkowski, 2009; Chomiczewski, 2011; Szczukocka, 2011; Wolny, 2013). 
Kluczowym elementem wszystkich definicji usług elektronicznych jest to, że są one świadczone przy wykorzystaniu sieci internetowej i sprzętu komputerowego (komputer, laptop, notebook) lub sprzętu mobilnego (tablet, smartfon itp.). Najczęściej nie jest to zupełnie nowy rodzaj usług, ale nowy sposób świadczenia tradycyjnych usług (Dominiak, 2008).

W ustawie o świadczeniu usług drogą elektroniczną (Dz.U. nr 144 z 2002 r., poz. 1204) usługi elektroniczne definiowane są jako: „wykonanie usługi świadczonej bez jednoczesnej obecności stron (na odległość), poprzez przekaz danych na indywidualne żądanie usługobiorcy, przesyłanej i otrzymywanej za pomocą urządzeń do elektronicznego przetwarzania, włącznie z kompresją cyfrową, i przechowywania danych, która jest w całości nadawana, odbierana lub transmitowana za pomocą sieci telekomunikacyjnej".

Tab. 1. Porównanie cech produktu, usługi tradycyjnej i elektronicznej

\begin{tabular}{|l|l|l|}
\hline \multicolumn{1}{|c|}{ Produkt } & \multicolumn{1}{c|}{$\begin{array}{c}\text { Usługa } \\
\text { elektroniczna }\end{array}$} & \multicolumn{1}{c|}{$\begin{array}{c}\text { Usługa } \\
\text { tradycyjna }\end{array}$} \\
\hline materialny charakter & $\begin{array}{l}\text { niematerialny charakter, ale } \\
\text { wykorzystuje materialne media }\end{array}$ & niematerialny charakter \\
\hline $\begin{array}{l}\text { rozdzielność produkcji } \\
\text { i konsumpcji }\end{array}$ & $\begin{array}{l}\text { rozdzielność produkcji } \\
\text { i konsumpcji }\end{array}$ & $\begin{array}{l}\text { nierozdzielność produkcji } \\
\text { i konsumpcji }\end{array}$ \\
\hline możliwość opatentowania & prawa autorskie & brak możliwości opatentowania \\
\hline brak możliwości kopiowania & istnieje możliwość kopiowania & brak możliwości kopiowania \\
\hline $\begin{array}{l}\text { użycie jest jednoznaczne } \\
\text { z konsumpcją }\end{array}$ & $\begin{array}{l}\text { użycie nie jest jednoznaczne } \\
\text { z konsumpcją }\end{array}$ & $\begin{array}{l}\text { użycie jest jednoznaczne } \\
\text { z konsumpcją }\end{array}$ \\
\hline łatwość wyceny & trudna do wyceny & trudna do wyceny \\
\hline
\end{tabular}

Źródło: opracowanie własne na podstawie: Hofacker, Goldsmith, Swilley, Bridges (2007)

Usługi elektroniczne różnią się więc od usług tradycyjnych. Hofacker, Goldsmith, Swilley i Bridges (2007), rozpatrując różnice pomiędzy usługami tradycyjnymi i elektronicznymi, brali pod uwagę najczęściej wymienianie cechy usług: niematerialność, niejednorodność, nierozdzielność produkcji i konsumpcji oraz nietrwałość (nie mogą być magazynowane, odsprzedawane). W swojej pracy sytuują oni usługi elektroniczne pomiędzy usługami tradycyjnymi a dobrami materialnymi. Niektóre cechy usług elektronicznych bardziej upodabniają je bowiem do dóbr materialnych niż do tradycyjnie pojmowanej działalności usługowej.

Podobnie jak w przypadku produktów materialnych, także w e-usługach możliwe jest rozdzielenie procesów produkcji i konsumpcji (co jest niemożliwe w przypadku usług tradycyjnych). Podobnie sytuacja wygląda w odniesieniu do ochrony praw autorskich i ochrony patentowej. Jest ona możliwa jedynie w przypadku dóbr i usług elektronicznych. Niematerialność jest co prawda domeną obu rodzajów usług, jednakże w procesie świadczenia usług elektronicznych niezbędne jest zastosowanie materialnych „mediów”. Usługi elektroniczne są także bardziej homogeniczne. Ta jednorodność wynika z faktu standaryzacji i zautomatyzowania świadczenia e-usług, mniejszego nakładu pracy człowieka, a co za tym idzie, także mniejszego ryzyka błędu. Usługa elektroniczna charakteryzuje się też mniejszym stopniem nietrwałości. Oprogramowanie 
Tab. 2. Charakterystyka wybranych usług elektronicznych

\begin{tabular}{|c|c|}
\hline Usługa & Charakterystyka \\
\hline $\begin{array}{l}\text { elektroniczna administracja } \\
\text { (e-government) }\end{array}$ & $\begin{array}{l}\text { świadczenie usług dla obywateli oraz dostarczanie informacji pu- } \\
\text { blicznych za pomocą sieci internet, poprzez zdalny dostęp do różnego } \\
\text { rodzaju aktów prawnych, informacji, m.in. na temat realizowanych } \\
\text { przetargów czy inwestycji, oraz poprzez elektroniczną wymianę ko- } \\
\text { respondencji, możliwość pobierania formularzy i ich odsyłania }\end{array}$ \\
\hline $\begin{array}{l}\text { handel elektroniczny } \\
\text { (e-commerce) }\end{array}$ & $\begin{array}{l}\text { obejmuje kupno oraz sprzedaż towarów i usług w internecie, przeka- } \\
\text { zywanie zamówień i potwierdzeń oraz obsługę płatności bezgotów- } \\
\text { kowych; najczęściej spotykaną formą e-commerce są sklepy interne- } \\
\text { towe }\end{array}$ \\
\hline $\begin{array}{l}\text { elektroniczna (zdalna) edukacja } \\
\text { (e-learning) }\end{array}$ & $\begin{array}{l}\text { nowoczesna forma edukacji oparta na technologiach informacyjnych, } \\
\text { nauczanie na odległość z wykorzystaniem technik komputerowych } \\
\text { i internetu, oznacza wspomaganie dydaktyki za pomocą komputerów } \\
\text { i sieci internet; pozwala na ukończenie kursu, szkolenia, studiów oraz } \\
\text { wspiera tradycyjny proces nauczania }\end{array}$ \\
\hline $\begin{array}{l}\text { usługi medyczne na odległość } \\
\text { (zdalna medycyna) (e-health) }\end{array}$ & $\begin{array}{l}\text { to działania obejmujące profilaktykę zdrowotną oraz usługi zwięk- } \\
\text { szające dostęp do opieki zdrowotnej, podnoszące jej jakość i efek- } \\
\text { tywność, umożliwiające rejestracje na wizyty lekarskie, konsultacje } \\
\text { medyczne i przeprowadzenie niektórych badań }\end{array}$ \\
\hline $\begin{array}{l}\text { elektroniczna bankowość } \\
\text { (e-banking) }\end{array}$ & $\begin{array}{l}\text { jest usługą oferowaną przez banki, która umożliwia klientowi dostęp } \\
\text { do jego rachunku za pośrednictwem komputera i łącza telekomunika- } \\
\text { cyjnego. W zależności od banku i wykorzystywanego oprogramowa- } \\
\text { nia może ona pozwalać jedynie na wgląd w stan konta i ewentualne } \\
\text { uzyskanie ogólnych informacji na temat usług banku lub również na } \\
\text { dokonywanie operacji na rachunkach, takich jak przelewy czy zakła- } \\
\text { danie lokat }\end{array}$ \\
\hline $\begin{array}{l}\text { elektroniczny marketing } \\
\text { (e-marketing) }\end{array}$ & $\begin{array}{l}\text { polega na wykorzystywaniu internetu w celu promocji produktów lub } \\
\text { usług za pomocą takich form przekazu, jak np.: wiadomości e-mail, } \\
\text { banery reklamowe, promocyjne strony WWW, biuletyny elektronicz- } \\
\text { ne i inne }\end{array}$ \\
\hline
\end{tabular}

Źródło: opracowanie własne

może być wielokrotnie wykorzystywane bez zużywania się i, co więcej, przekazywane do wykorzystania innym użytkownikom (tab. 1).

Usługi elektroniczne najczęściej klasyfikowane są za względu na odbiorcę lub rodzaj świadczonych usług (Dominiak, 2008). Ze względu na odbiorcę usługi elektroniczne można podzielić na usługi dla przedsiębiorstw oraz usługi dla odbiorców indywidualnych. Ze względu na rodzaj świadczonych usług wyróżnia się najczęściej:

- elektroniczną administrację (e-government),

- handel elektroniczny (e-commerce),

- elektroniczną edukację (e-learning),

- usługi medyczne na odległość (e-health),

- elektroniczną bankowość (e-banking),

- elektroniczny marketing (e-marketing),

- elektroniczne ubezpieczenia,

- elektroniczną księgowość. 
Tab. 3. Wybrane prace dotyczące usług elektronicznych

\begin{tabular}{|l|l|}
\hline \multicolumn{2}{|c|}{ Nowe formy świadczenia usług - usługi elektroniczne } \\
\hline Prace teoretyczne & Uwarunkowania rozwoju usług elektronicznych \\
\hline Relich (2010) & $\begin{array}{l}\text { Rola usług elektronicznych w rozwoju nowoczesnej } \\
\text { gospodarki }\end{array}$ \\
\hline Dominiak (2008, 2011) & Zróżnicowanie poziomu rozwoju usług elektronicznych \\
\hline $\begin{array}{l}\text { Rust, Kannan (2003), Jarvinen, Lehtinen (2004), } \\
\text { Hofacker, Goldsmith, Swilley, Bridges (2007), } \\
\text { Scupola, Henten, Nicolajsen (2009), Wolny } \\
\text { (2013) }\end{array}$ & Koncepcja usług elektronicznych. \\
\hline Prace empiryczne & $\begin{array}{l}\text { Kaczmarek-Śliwińska (2004), Jaros (2005), } \\
\text { Chmielarz (2007), Minkowski, Motek, Perdał } \\
\text { (2009), Taraszkiewicz (2010), Drobiazgiewicz } \\
\text { (2011) }\end{array}$ \\
\hline $\begin{array}{l}\text { Księżopolski, Kotulski (2004) } \\
\text { administracji (e-government) }\end{array}$ \\
\hline $\begin{array}{l}\text { Szcześ, Jakubiec (2002), Polasik (2007), } \\
\text { Weltrowska-Jęch (2009) }\end{array}$ & $\begin{array}{l}\text { Poziom i perspektywy rozwoju handlu elektronicznego } \\
\text { (e-commerce) }\end{array}$ \\
\hline
\end{tabular}

Źródło: opracowanie własne

Charakterystyka wybranych rodzajów usług elektronicznych znajduje się w tab. 2. Podobna klasyfikacja usług elektronicznych występuje m.in. w pracach Wolnego (2013), Batko, Billewicz (2013), Dąbrowskiej, Janoś-Kresło i Wódkowskiego (2009). W klasyfikacjach tych dodaje się także: e-komunikację (możliwość rozmów i wymiany korespondencji poprzez komunikatory typu Skype, Gadu-Gadu oraz pocztę elektroniczną), e-pracę (telepraca), e-turystykę, e-kulturę.

Interesującą próbą zestawienia usług tradycyjnych i elektronicznych są klasyfikacje Hofackera, Goldsmitha, Swilley i Bridges (2007) oraz Wolnego (2013). Hofacker, Goldsmith, Swilley i Bridges (2007) proponują klasyfikację usług elektronicznych w relacji do usług tradycyjnych, wyróżniając trzy istniejące typy usług elektronicznych:

- uzupełniające istniejące tradycyjne usługi (np. śledzenie przez internet paczek dostarczanych przez firmy kurierskie, wybór miejsc na pokładach samolotów),

- substytuty istniejących tradycyjnych usług (np. wypożyczalnie filmów),

- unikalne nowe usługi, które nie mogłyby funkcjonować poza siecią (gry sieciowe, Google Maps z możliwościami m.in. obserwacji natężenia ruchu).

Wolny (2013) wyróżnia natomiast następujące typy oferowanych na rynku usług tradycyjnych i e-usług:

- usługi świadczone tylko online (gry sieciowe),

- usługi świadczone zarówno online, jak i w tradycyjny sposób (handel),

- usługi świadczone tradycyjnie, ale informacja o nich odbywa się online (rezerwacja, zakup biletu).

Literatura dotycząca usług elektronicznych obejmuje głównie prace analizujące usługi elektroniczne w wąskim zakresie, dotyczące wybranych rodzajów e-usług (np. dotyczące wykorzystania e-learningu w przedsiębiorstwach czy szkołach wyższych). 
Publikowane raporty dotyczą głównie wykorzystania handlu elektronicznego (E-commerce w Polsce Gemiusa). Brakuje kompleksowych badań dotyczących wykorzystywania usług elektronicznych przez przedsiębiorstwa i gospodarstwa domowe i jego zróżnicowania w skali regionalnej. Wybrane prace w literaturze przedmiotu w zakresie usług elektronicznych prezentuje tab. 3.

\section{POZIOM WYKORZYSTANIA USŁUG ELEKTRONICZNYCH W POLSCE NA TLE INNYCH PAŃSTW EUROPEJSKICH}

Polska należy do krajów o stosunkowo niskim poziomie dostępności internetu w porównaniu z innymi krajami europejskimi, zarówno w przypadku gospodarstw domowych, jak i przedsiębiorstw. W odniesieniu do gospodarstw domowych, według danych GUS w 2015 roku, dostęp do internetu deklarowało 75,8\%. Większą dostępnością sieci cechowały się gospodarstwa domowe z dużych miast $(81,2 \%)$, mniejszą - z terenów wiejskich (72\%). W przypadku przedsiębiorstw - według danych GUS w 2015 roku dostęp do sieci internetowej miało 93\% przedsiębiorstw.

Podobnie sytuacja kształtuje się w odniesieniu do poziomu wykorzystania e-usług. Wskaźnik osób robiących zakupy przez internet (w ciągu 3 miesięcy poprzedzających badanie) wynosił w 2014 roku w krajach UE średnio 41\% (ogółu badanych). Kraje UE charakteryzowały się jednak dużym zróżnicowaniem w zakresie korzystania z handlu elektronicznego. Największy odsetek respondentów dokonywał zakupów przez internet w państwach skandynawskich: Danii, Norwegii, Szwecji, oraz w Niemczech i Wielkiej Brytanii (powyżej 60\% respondentów). Nieco mniejszą wartością wskaźnika cechowały się Holandia, Finlandia i Luksemburg. Wartości powyżej średniej unijnej odnotowano także we Francji, Austrii, Irlandii, Belgii.

Zdecydowanie mniej powszechne jest wykorzystanie e-handlu w krajach Europy Południowej i Środkowo-Wschodniej, w tym Polski (11-40\%). Najniższe wartości przyjął wskaźnik w Bułgarii i Rumunii (poniżej 10\%). 0 ile jednak w przypadku państw Europy Południowej wynika to raczej ze stylu życia i preferowania kontaktów bezpośrednich w realizacji usług, o tyle w państwach Europy Środkowo-Wschodniej jest raczej rezultatem zacofania technologicznego.

Handel elektroniczny należy do najdynamiczniej rozwijających się rodzajów usług elektronicznych. Według danych Eurostat, w ostatnich latach nastąpił zdecydowany wzrost odsetka osób kupujących przez internet, z 18\% w 2005 roku do 41\% w 2014 roku. W przypadku Polski odsetek ten wzrósł z 5\% do 24\%.

Eurostat publikuje także dane dotyczące interakcji mieszkańców z władzami publicznymi (w ciągu 12 miesięcy poprzedzających badanie). Średnia wartość tego wskaźnika w UE wynosiła w 2014 roku 47\%. Ponownie najwyższe wartości odsetka odnotowano w krajach Europy Północnej i Zachodniej. Najwyższymi wartościami wskaźnika cechowały się Dania, Szwecja, Norwegia, Finlandia (powyżej 80\% respondentów). Z kolei najniższy odsetek osób korzystających z usług e-administracji wystąpił w Rumunii (10\%) oraz Bułgarii, Polsce (27\%) i we Włoszech.

Sytuacja w zakresie korzystania z usług elektronicznych przez przedsiębiorstwa w UE kształtowała się podobnie (tab. 4). 
Tab. 4. Odsetek przedsiębiorstw kontaktujących się z administracją publiczną przez internet w 2013 roku

\begin{tabular}{|c|c|c|c|}
\hline \multicolumn{2}{|c|}{$\begin{array}{l}\text { Odsetek przedsiębiorstw korzystających } \\
\text { z e-administracji }\end{array}$} & \multicolumn{2}{|c|}{$\begin{array}{l}\text { Odsetek przedsiębiorstw dokonujących zamówień } \\
\text { przez internet }\end{array}$} \\
\hline $\begin{array}{l}\text { Odsetek } \\
\text { przedsiębiorstw }\end{array}$ & Kraje & $\begin{array}{l}\text { Odsetek } \\
\text { przedsiębiorstw }\end{array}$ & Kraje \\
\hline powyżej 95\% & $\begin{array}{l}\text { Estonia, Finlandia, Islandia, } \\
\text { Szwecja, Dania, Francja, } \\
\text { Irlandia }\end{array}$ & powyżej 25\% & Islandia, Norwegia, Dania \\
\hline $85-90 \%$ & $\begin{array}{l}\text { Czechy, Słowenia, Słowacja, } \\
\text { Łotwa, Austria, Wielka } \\
\text { Brytania }\end{array}$ & $20-25 \%$ & $\begin{array}{l}\text { Szwecja, Wielka Brytania, } \\
\text { Irlandia, Francja, Belgia, } \\
\text { Austria Niemcy, Holandia }\end{array}$ \\
\hline $85-90 \%$ & $\begin{array}{l}\text { Polska, Belgia, Holandia, } \\
\text { Luksemburg }\end{array}$ & $16-19 \%$ & $\begin{array}{l}\text { Hiszpania, Portugalia, } \\
\text { Słowenia, Francja, Austria }\end{array}$ \\
\hline \multirow[t]{2}{*}{ poniżej 85\% } & \multirow[t]{2}{*}{$\begin{array}{l}\text { Włochy, Grecja, Hiszpania, } \\
\text { Bułgaria, Rumunia, Węgry }\end{array}$} & $10-15 \%$ & $\begin{array}{l}\text { Cypr, Polska, Węgry, } \\
\text { Słowacja, Estonia }\end{array}$ \\
\hline & & poniżej $10 \%$ & $\begin{array}{l}\text { Grecja, Włochy, Rumunia, } \\
\text { Bułgaria, Łotwa }\end{array}$ \\
\hline
\end{tabular}

Źródło: opracowanie własne na podstawie danych Eurostatu

\section{Poziom RozWoju E-USŁUG W WiELKOPOLSCE}

Dostęp do internetu zarówno w gospodarstwach domowych, jak i przedsiębiorstwach charakteryzował się zróżnicowaniem regionalnym. Najniższym odsetkiem przedsiębiorstw posiadających dostęp do internetu cechowało się województwo świętokrzyskie $(90,6 \%)$, najwyższy odnotowano w województwie dolnośląskim (95\%). Województwo wielkopolskie znalazło się wśród województw z nieco powyżej przeciętnymi wartościami tego wskaźnika (93,8\%).

W odniesieniu do branż, zarówno w Polsce, jak i w województwie wielkopolskim, najczęściej dostępem do sieci charakteryzowały się przedsiębiorstwa branży komputerowej, informatycznej, sektora ICT (ponad 99\%). Nieco mniejszy udział przedsiębiorstw z dostępem do internetu odnotowano w przypadku firm świadczących usługi dla biznesu (działalność profesjonalna, naukowa i techniczna, obsługa nieruchomości około 97\%) i usługi transportowe (96\%). Najniższym odsetkiem cechowały się przedsiębiorstwa branży gastronomicznej i hotelarskiej $(87,6 \%)$.

Przedsiębiorstwa prowadzące handel za pośrednictwem sieci komputerowych częściej dokonywały zakupów niż sprzedaży. W województwie wielkopolskim odsetek przedsiębiorstw dokonujących zamówień przez internet wynosił 22,7\% i był nieco niższy niż w całym kraju, gdzie wynosił 23,6\%. Zdecydowanie najbardziej popularną e-usługą wśród przedsiębiorstw była e-administracja. W 2014 roku korzystało z niej aż 88\% badanych przedsiębiorstw (w przynajmniej jednej z wymienionych aktywności: w zakresie pozyskiwania informacji, pobierania formularzy, odsyłania wypełnionych formularzy lub obsługi procedur administracyjnych całkowicie drogą elektroniczną) w Polsce i niemal 90\% w Wielkopolsce. 
Tab. 5. Odsetek przedsiębiorstw i gospodarstw domowych z dostępem do internetu i korzystających z usług elektronicznych (\%)

\begin{tabular}{|c|c|c|c|c|c|c|}
\hline & \multicolumn{2}{|c|}{$\begin{array}{c}\text { Dostęp do sieci } \\
\text { internetowej }\end{array}$} & \multicolumn{2}{|c|}{$\begin{array}{l}\text { Korzystanie z internetu } \\
\text { w kontaktach } \\
\text { z administracją publiczną } \\
\text { (w ciągu } 12 \text { miesięcy } \\
\text { poprzedzających } \\
\text { badanie) }\end{array}$} & \multicolumn{2}{|c|}{$\begin{array}{c}\text { Korzystanie z e-handlu - } \\
\text { zakupy } \\
\text { (w ciągu } 3 \text { miesięcy } \\
\text { poprzedzających } \\
\text { badanie) }\end{array}$} \\
\hline & 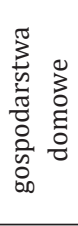 & 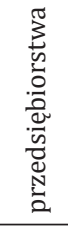 & 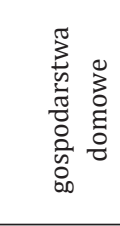 & 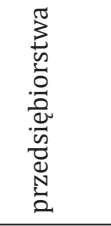 & 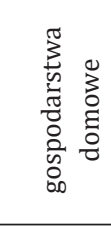 & 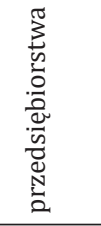 \\
\hline Polska & 73,8 & 93,1 & 26,9 & 88,0 & 24,5 & 23,6 \\
\hline Wielkopolska & 77,8 & 93,8 & 20,7 & 89,8 & 22,5 & 22,7 \\
\hline
\end{tabular}

Źródło: dane GUS

\section{WYNIKI BADAŃ ANKIETOWYCH}

Badania prowadzone przez GUS dotyczące korzystania z e-usług nie dają odpowiedzi na pytanie o popularność korzystania z różnych ich rodzajów, na temat czynników wpływających na decyzję korzystania z tych usług, barier, a także częstotliwości ich wykorzystywania. Badanie przeprowadzone w ramach prac nad artykułem stanowi więc pewne uzupełnienie i uszczegółowienie informacji publikowanych przez GUS. Badana próba wynosiła 508 przedsiębiorstw i 656 gospodarstw domowych zlokalizowanych na obszarze województwa wielkopolskiego.

Ponieważ badania prowadzone w tym zakresie (m.in. przez GUS) dowodzą, że dostępność internetu i - co za tym idzie - wykorzystanie usług elektronicznych są zależne m.in. od poziomu urbanizacji i wielkości zamieszkiwanego ośrodka oraz poziomu rozwoju społeczno-gospodarczego, wybrano próbę warstwową, uwzględniając wymienione kryteria. Badanie przeprowadzono w 2015 roku w Poznaniu i aglomeracji poznańskiej (jednostka reprezentująca duże miasta), w Koninie (miasto średniej wielkości, mające status miasta na prawach powiatu) oraz w mniejszych ośrodkach na terenie powiatów: wągrowieckiego, obornickiego, konińskiego, poznańskiego.

Struktura próby respondentów według płci, wieku i wykształcenia nawiązuje do struktury populacji generalnej. Występująca nadreprezentacja osób młodszych wynika z faktu odmowy wzięcia udziału w badaniu osób reprezentujących najstarszą grupę wiekową. Podobną procedurę zastosowano w przypadku doboru próby przedsiębiorstw. Struktura próby nawiązuje do struktury populacji, choć występuje tu nadreprezentacja przedsiębiorstw usługowych (przede wszystkim handlowych), co także związane jest z odmową udziału w badaniach firm produkcyjnych. 


\section{GOSPODARSTWA DOMOWE}

Niemal 80\% badanych gospodarstw domowych posiada dostęp do internetu. Odsetek respondentów deklarujących korzystanie z sieci internetowej był nawet wyższy i wynosił $82 \%$. Respondenci, którzy nie posiadali dostępu do internetu w domu, korzystali z niego w miejscu pracy, szkole lub miejscach publicznych (np. restauracjach, kawiarniach).

Odsetek respondentów wykorzystujących internet był zróżnicowany ze względu na wiek. Wszyscy respondenci poniżej 25 lat i niemal wszyscy poniżej 45 roku życia (98\%) korzystali z internetu. Odsetek osób w wieku 46-65 lat korzystających z sieci wynosił 78\%, a w najstarszej grupie wiekowej - 16\% (ryc. 1).

Nieco większy udział osób korzystających z internetu w porównaniu z badaniami prowadzonymi przez Główny Urząd Statystyczny wynikać może ze wspomnianej wcześniej nadreprezentacji respondentów z młodszych grup wiekowych, którzy zdecydowanie częściej korzystają z internetu.

Wśród usług elektronicznych respondenci najczęściej korzystali z usług bankowych (75\%) i handlowych (56\%). Nieco mniejszy odsetek respondentów deklarował korzystanie z usług elektronicznej administracji (35\%) oraz elektronicznych usług medycznych. Pozostałe rodzaje usług cieszyły się zdecydowanie mniejszą popularnością (ryc. 2).

Z usług elektronicznej bankowości korzystano głównie w zakresie obsługi i sprawdzania stanu konta i dokonywania przelewów, zdecydowanie rzadziej do zakupu różnych produktów finansowych, zakładania lokat itp. Usługi elektronicznej administracji związane były głównie z zasięganiem informacji o lokalizacji, godzinach urzędowania oraz prowadzonych procedurach (40\%). Około 30\% respondentów korzystało z zamieszczonych na stronach internetowych urzędów formularzy, ale nieliczni odsyłali je wypełnione (co zresztą wynika nie tyle z braku chęci, ile z braku takich możliwości po stronie urzędu).

Ryc. 1. Struktura korzystających z internetu według wieku

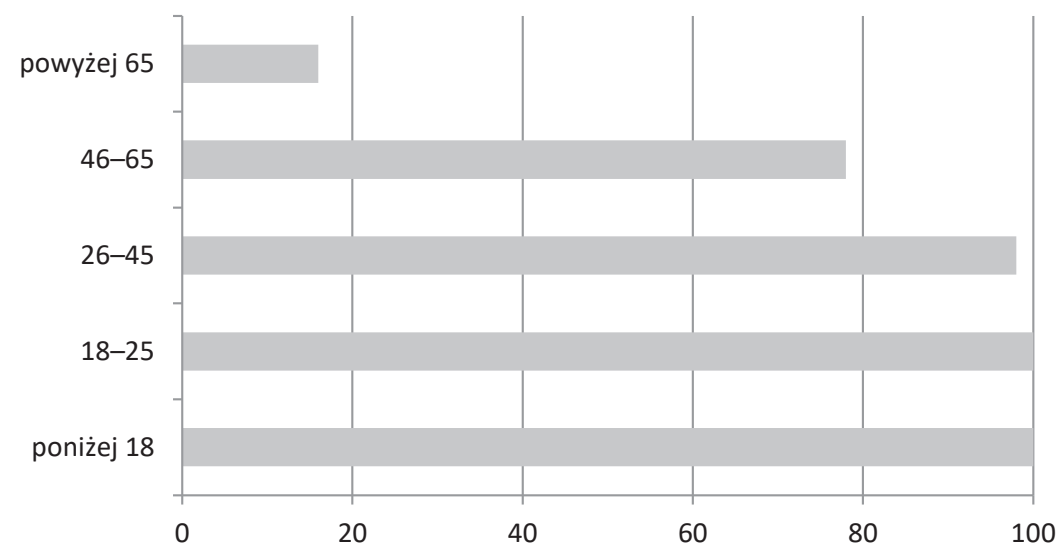

Źródło: opracowanie własne na podstawie badań ankietowych 
Ryc. 2. Rodzaje wykorzystywanych usług elektronicznych

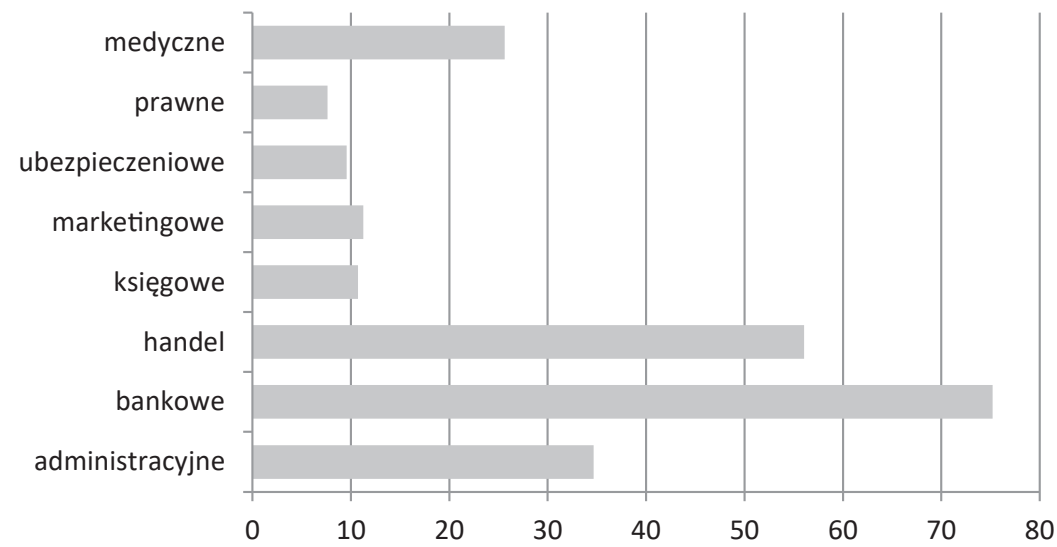

Źródło: opracowanie własne na podstawie badań ankietowych

Ryc. 3. Powody korzystania z usług elektronicznych

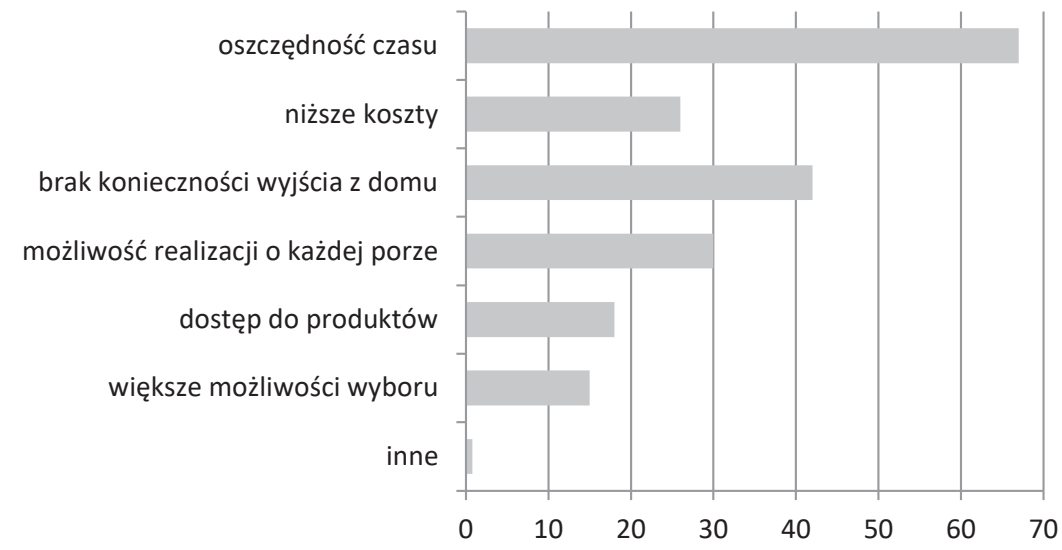

Źródło: opracowanie własne na podstawie badań ankietowych

W zakresie elektronicznej edukacji 38\% badanych korzystało z różnego rodzaju materiałów dydaktycznych zamieszczonych w sieci, a 10\% odbyło internetowe kursy i szkolenia. Natomiast w zakresie medycznych usług elektronicznych najczęściej korzystano z informacji na temat lokalizacji, godzin przyjmowania lekarzy (29\%) oraz umawiania się na wizytę (17\%). Jedynie $9 \%$ konsultowało się przez internet w zakresie doraźnej pomocy medycznej.

Najczęściej wymienianymi powodami korzystania z usług elektronicznych były: oszczędność czasu (67\%), na który zwracali uwagę szczególnie młodzi respondenci, a także brak konieczności wychodzenia z domu (42\%) i możliwość realizacji usług o każdej porze (30\%) (ryc. 3). Wśród głównych barier korzystania z internetu wymieniano przede wszystkim brak zaufania do takiej formy realizacji usług (63\%) oraz 
Ryc. 4. Bariery korzystania z usług elektronicznych

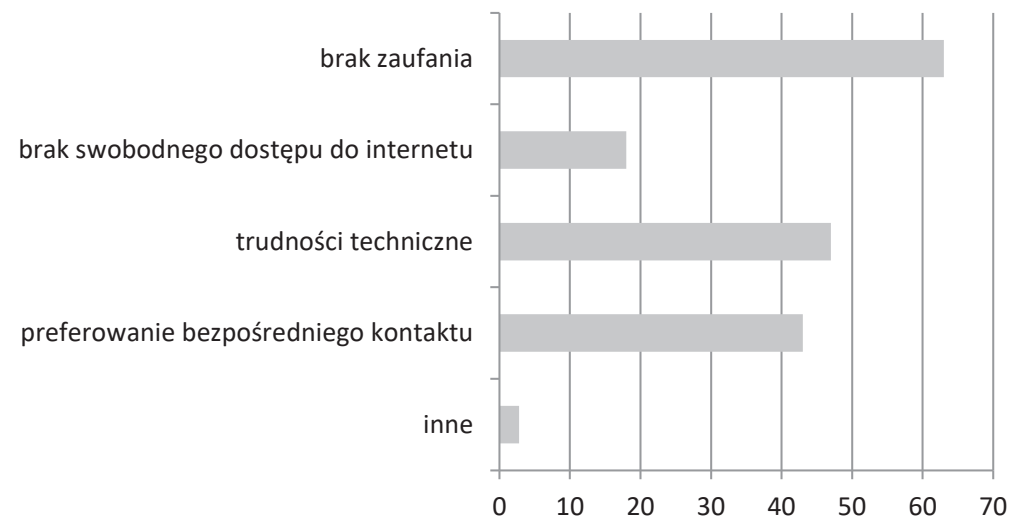

Źródło: opracowanie własne na podstawie badań ankietowych

trudności techniczne (47\%). Te ostatnie najczęściej deklarowane były przez respondentów z najstarszej grupy wiekowej (ryc. 4). W przypadku niemal 44\% badanych osób istotną barierę stanowiło preferowanie bezpośrednich kontaktów przy realizacji usług, a 18\% jako barierę wymieniło brak swobodnego dostępu do internetu.

Jeśli chodzi o częstotliwość korzystania z usług elektronicznych, to najczęściej respondenci korzystali z elektronicznej bankowości. 11\% badanych korzystało z e-bankowości codziennie, a dalsze 30\% kilka razy w tygodniu. Rzadziej respondenci korzystali z handlu elektronicznego. W tym przypadku najczęściej deklarowaną odpowiedzią była odpowiedź: „raz w miesiącu” (27\%). Jeszcze rzadziej, w zależności od potrzeb, korzystano z elektronicznej administracji i medycyny.

\section{PRZEDSIĘBIORSTWA}

Zdecydowana większość badanych przedsiębiorstw (90\%) zadeklarowała wykorzystywanie sprzętu komputerowego i sieci internetowej. Brak komputerów i dostępu do sieci internetowej dotyczył głównie małych firm zatrudniających mniej niż dziewięć osób z branży handlowej i gastronomicznej.

W zakresie usług elektronicznych firmy korzystały głównie z usług bankowych (80\%), handlowych (58\%) i marketingowych (56\%). Nieco niższym poziomem wykorzystania cechowały się usługi administracyjne (48\%) i księgowe (36\%). Najczęściej firmy korzystały z usług bankowości elektronicznej. Ponad 40\% firm korzystało z tych usług codziennie, a dalsze 20\% kilka razy w tygodniu. Około 30\% badanych przedsiębiorstw codziennie korzystało też z elektronicznych usług handlowych i marketingowych. Zdecydowanie rzadziej wykorzystywanymi usługami były e-administracja i e-księgowość (głównie raz w miesiącu lub rzadziej) (ryc. 5).

Przyczyny korzystania z usług elektronicznych są w przypadku przedsiębiorstw podobne jak w przypadku mieszkańców. Firmy wskazywały na oszczędność czasu 
Ryc. 5. Rodzaj i częstotliwość wykorzystywanych usług elektronicznych

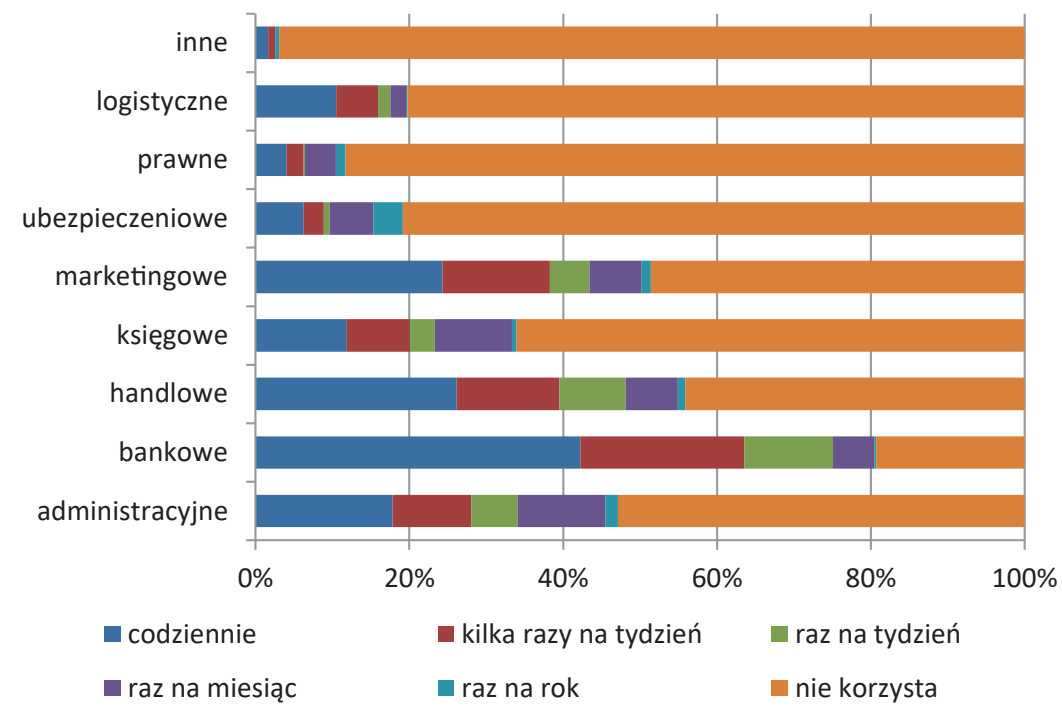

Źródło: opracowanie własne na podstawie badań ankietowych

(82\% korzystających z usług elektronicznych), wygodę (81\%), możliwość realizacji usługi o każdej porze (66\%) i niższe koszty (60\%). Około 36\% badanych firm widzi potrzebę zwiększenia zakresu korzystania z usług elektronicznych, przede wszystkim w zakresie usług handlowych i marketingowych.

\section{PodsumoWANIE}

Przeprowadzona w artykule analiza prowadzi do następujących wniosków:

- Zdecydowana większość respondentów, zarówno gospodarstw domowych (80\%), jak i firm (90\%), posiada dostęp do internetu i korzysta z niego.

- Najczęściej wykorzystywanymi usługami elektronicznymi są usługi bankowe. Korzystało z nich aż $75 \%$ badanych mieszkańców i ponad $80 \%$ badanych firm, przede wszystkim w zakresie sprawdzania stanu konta, dokonywania przelewów i płatności w sklepach internetowych.

- Nieco mniejszym zainteresowaniem cieszyły się elektroniczne usługi handlowe i edukacyjne, administracyjne oraz medyczne - w przypadku gospodarstw domowych, i marketingowe - w przypadku firm.

- Głównymi czynnikami wpływającymi na korzystanie z usług elektronicznych, zarówno w przypadku mieszkańców, jak i przedsiębiorstw, są przede wszystkim: oszczędność czasu, oszczędność kosztów i wygoda, a także elastyczny czas realizacji usług.

- Podstawowymi barierami w korzystaniu z usług elektronicznych są: brak zaufania do takiej formy realizacji usług (60\% respondentów), trudności techniczne (powyżej 40\% respondentów) i preferowanie kontaktów bezpośrednich. 
- Usługami elektronicznymi, z których najwcześniej zaczęli korzystać mieszkańcy, były usługi bankowe i handlowe (aż połowa ich użytkowników korzysta z nich od ponad pięciu lat). Nieco później zaczęto korzystać z elektronicznych usług administracyjnych oraz medycznych. W przypadku przedsiębiorstw również najszybciej wykorzystywanymi usługami elektronicznymi były usługi bankowe, a też marketingowe, nieco później - handlowe i administracyjne. Zauważalne jest także coraz większe zainteresowanie elektronicznymi usługami edukacyjnymi (zarówno w przypadku osób, jak i firm).

- Jeśli chodzi o częstotliwość korzystania z usług elektronicznych, najczęściej respondenci korzystają z usług bankowych - nawet $11 \%$ korzysta z nich codziennie, a kolejne 30\% kilka razy w tygodniu. Zdecydowanie rzadziej respondenci korzystają z usług handlowych (odpowiednio 3 i 11\%). Przedsiębiorstwa znacznie częściej korzystały z usług elektronicznych - najczęściej z bankowości (ponad 40\% korzysta z niej codziennie) i usług handlowych (30\%). Firmy często korzystają także z elektronicznych usług marketingowych.

\section{Literatura \\ References}

Batko, K., Billewicz, G. (2013). E-usługi w biznesie i administracji publicznej. W: B. Kos (red.). Studia Ekonomiczne / Uniwersytet Ekonomiczny w Katowicach, 136, 47-63.

Castells, M. (2007). Społeczeństwo sieci. Warszawa: Wydawnictwo Naukowe PWN.

Chmielarz, W. (2007). Systemy biznesu elektronicznego. Warszawa: Difin.

Chomiczewski, W., Klafkowska-Waśniowska, K., Lubasz, D., Namysłowska, M. (2011). Świadczenie usług droga elektronicznq oraz dostęp warunkowy. Komentarz do ustaw. Warszawa: LexisNexis.

Dąbrowska, A., Janoś-Kresło, M., Wódkowski, A. (2009). E-usługi a społeczeństwo informacyjne. Warszawa: Difin.

Dominiak, J. (2008). Poziom rozwoju usług elektronicznych w Polsce na tle państw Unii Europejskiej. W: J. Dominiak (red.). Przemiany w sferze usług w Polsce. Poznań: Bogucki Wydawnictwo Naukowe, 9-28.

Dominiak, J. (2011). Level of development of electronic services in Poland compared with European Union. Quaestiones Geographicae, 30(2), 57-70.

Drobiazgiewicz, J. (2011). Stan rozwoju usług e-administracji w Polsce. Zeszyty Naukowe. Studia Informatica, 28, 411-420.

Goliński, M. (2004). Społeczeństwo informacyjne - problemy definicyjne i problemy pomiaru. W: H.L. Haber (red.). Polskie doświadczenia w kształtowaniu społeczeństwa informacyjnego: dylematy cywilizacyjno-kulturowe. Materiały ogólnopolskiej konferencji naukowej w Krakowie. Pozyskano z http://winntbg.bg.agh.edu.pl/skrypty/0037/cz0-r11.html

Hofacker, C.F., Goldsmith, R.G., Swilley, E. i Bridges, E. (2007). E-Services: A Synthesis and Research Agenda. Journal of Value Chain Management, 1(1/2), 13-44.

Jaros, I. (2005). E-governement. Administracja publiczna w społeczeństwie informacyjnym - wprowadzenie teoretyczne. Zeszyty Naukowe Politechniki Ślq̨skiej. Organizacja i Zarzq̨dzanie, 31, 25-35

Jarvinen, R., Lehtinen, U. (2004). Services, e-Services and e-Service Innovations - Combination of Theoretical and Practical Knowledge. Frontiers of E-business Research. Tampere: University of Technology and University of Tampere. 
Kaczmarek-Śliwińska, M. (2004). Stan e-government w Polsce. E-mentor, 5(7). Pozyskano z http://www.e-mentor.edu.pl/artykul/index/numer/7/id/100

Księżopolski, B., Kotulski, Z. (2004). Zagrożenia procesów komunikacyjnych e-commerce oraz sposoby przeciwdziałania. W: J. Kisielnicki (red.). Informatyka narzędziem współczesnego zarządzania. Warszawa: Polsko-Japońska Wyższa Szkoła Technik Komputerowych.

Minkowski, A., Motek, P., Perdał, R. (2009). Poziom zaawansowania wielkopolskich urzędów gmin $w$ zakresie informatyzacji i rozwoju elektronicznych usług publicznych. Poznań: Wydawnictwo M-Druk.

Polasik, M. (2007). Bankowość elektroniczna. Istota - stan - perspektywy. Warszawa: CeDeWu.

Relich, M. (2010). Uwarunkowania wdrożenia e-biznesu w małych i średnich przedsiębiorstwach. Zeszyty Naukowe Uniwersytetu Szczecińskiego. Problemy Zarządzania, Finansów i Marketingu, 58, 111-118.

Rust, R.T. (2004). The rise of e-service. Journal of Marketing, 68(1), 109-127.

Rust, R. T., Kannan, P. K. (2002). E-Service: New Directions in Theory and Practice. New York: M.E. Sharpe, Inc.

Rust, R.T., Kannan, P.K. (2003). E-service: A New Paradigm for Business in the Electronic Environment. Communications of the ACM, 46(6), 37-42.

Sasak, J. (2010). Rola elektronicznych usług publicznych w budowie gospodarki opartej na wiedzy. W: A. Noworól (red.). Jakość życia a procesy zarządzania rozwojem i funkcjonowaniem organizacji publicznych. Kraków: Instytut Spraw Publicznych Uniwersytetu Jagiellońskiego.

Scupola, A., Henten, A., Nicolajsen, H.W. (2009). E-Services: Characteristics, Scope and Conceptual Strengths. International Journal of E-Services and Mobile Applications, 1(3), 1-16.

Szcześ, M., Jakubiec, S. (2002). Elektroniczne usługi finansowe - charakterystyka rynku, wyzwania i inicjatywy regulacyjne. Materiały i Studia, 139.

Szczukocka, A. (2011). Rozwój usług elektronicznych w Polsce. Wiadomości Statystyczne 56(11), 74-84.

Taraszkiewicz, T. (2010). E-usługi w administracji publicznej na przykładzie samorządowej elektronicznej platformy informacyjnej w Gdańsku. Zeszyty Naukowe Uniwersytetu Szczecińskiego. Ekonomiczne Problemy Usług, 58, 417-425.

Weltrowska-Jęch, J. (2009). Rozwój usług bankowości elektronicznej w Polsce. W: J. Dominiak (red.). Przemiany w sferze usług w Polsce. Poznań: Bogucki Wydawnictwo Naukowe, 65-76.

Werner, P. (2003). Geograficzne uwarunkowania rozwoju infrastruktury społeczeństwa informacyjnego w Polsce. Warszawa: Uniwersytet Warszawski.

Wolny, R. (2013). Rynek e-usług w Polsce - funkcjonowanie i kierunki rozwoju. Katowice: Uniwersytet Ekonomiczny.

Joanna Dominiak, doktor, adiunkt w zakładzie Analizy Regionalnej Instytutu Geografii Społeczno-Ekonomicznej i Gospodarki Przestrzennej Uniwersytetu im. Adama Mickiewicza w Poznaniu. Zainteresowania naukowe koncentrują się wokół roli innowacyjności w kształtowaniu gospodarki opartej na wiedzy, wpływu otoczenia biznesu na rozwój regionów oraz przemian w strukturze usług.

Joanna Dominiak, Ph.D., an assistant professor in the Department of Regional Analysis in the Institute of Socio-Economic Geography and Spatial Management of Adam Mickiewicz University in Poznan. Her research interests revolve around the role of innovation in the development of the knowledge-based economy; the impact of the business environment on the development of regions; and changes in the structure of services.

\section{Adres/address:}

Uniwersytet im. A. Mickiewicza w Poznaniu Instytut Geografii Społeczno-Ekonomicznej i Gospodarki Przestrzennej

Zakład Analizy Regionalnej

ul. Dzięgielowa 27, 61-680 Poznań, Polska

e-mail: dominiak@amu.edu.pl 